\title{
Effect of Simvastatin on Male Albino Rats, Cytogenetic and Histochemical Studies
}

\author{
Rokaya H. Shalaby ${ }^{1}$, Laila A. Rashed ${ }^{2}$, Fatma M. Foda ${ }^{1}$, Afaf H. Kamel ${ }^{1}$, and Rana M. Adel ${ }^{1}$ \\ 1. Department of Zoology, Faculty of Women for Arts, Science and Education, Ain Shams \\ University, Cairo, Egypt. \\ 2. Department of Biochemistry, Faculty of Medicine, Cairo University, Cairo, Egypt.
}

\begin{abstract}
Introduction: Simvastatin belongs to statins drugs that are used globally for lowering blood cholesterol level in cardiovascular patients. Simvastatin can be considered as life threatening agent, since prolonged usage may cause myotoxicity. Materials \& methods: The present study was performed on 20 adult male rats which were divided into: Group I which was the control group that did not receive any treatments, and Group II which was the treated group that received $80 \mathrm{mg} / \mathrm{kg}$ b.wt/day of simvastatin for 46 days. All rats were submitted to bone marrow collection for the cytogenetics tests and gastrocnemoius muscles' biopsied were taken for the histochemical tests. Results: statistical analysis showed a non-significant increase in the mean of chromosomal aberrations (CAs) in the treated rats' cells comparing to the control samples. On the other hand, an observed non-significant decrease in the mean of total proteins (TP) content in rats' gastrocnemius muscles of Group II when compared to the control group. Whereas, noticed significant reduction in the mean of glycogen (Glyc.) content in rats' gastrocnemius muscles of the same group when compared to the control group. Conclusion: Simvastatin may lead to an increase in the incidence of (CAs) in bone marrow cells, and determination of TP and Glyc. content in skeletal muscle biopsies can be considered as indicators for muscle necrosis incidence. Recommendations: Simvastatin has to be prescribed carefully in patients suffering from hypercholesterolemia, precautions have to be taken into consideration since it may affect skeletal muscles' health and lead to muscle toxicity on the short or long run of usage.
\end{abstract}

\section{Introduction}

Statins are a widely used group of drugs which represent the main therapeutic class of lipid lowering drugs (Jasinska et al., 2007), and are prescribed for treatment of hypercholesterolaemia in atherosclerotic and coronary heart patients (Fischer et al., 2015).

Statins include seven drugs currently available within the class and approved by the FDA, which are: lovastatin, simvastatin, pravastatin, fluvastatin, atorvastatin, rosuvastatin, and pitavastatin according to Ahmad \& cheng, (2010).

Statins (3-hydroxy-3, methyl-glutaryl-CoA reductase inhibitors) mode of action based on inhibiting HMG Coenzyme A reductase (HMG-CoA reductase), which is the rate-limiting enzyme in cholesterol biosynthesis (Wilke et al., 2008). This leads to an inhibition in the rate-limiting step in cholesterol synthesis, thus, increasing the expression of LDL receptors, resulting in the rapid clearance of LDL from the blood (Iughetti et al., 2010). The liver is the target organ for the statins, since it is the major site of cholesterol biosynthesis, lipoprotein production and LDL catabolism.

Corresponding author: ranona.31wany@gmail.com 
However, cholesterol biosynthesis in extrahepatic tissues is necessary for normal cell function as discussed by Bouitbir et al., (2012a).

But it is worth mentioning that there are growing concerns among patients and physicians on the safety of short-term and long-term use of statins and their adverse effects, especially in incidence muscle toxicity (Maghsoodi \& Wierzbicki, 2016).

Several theories have been proposed for explaining the mechanism of muscle injury after statins intake, including the lowering of ubiquinone levels or the alteration of sarcolemma cholesterol content due to inhibition of the mevalonate pathway, or the induction of apoptosis and proteolysis due to increased $\mathrm{Ca}^{2+}$ release as reported by Inoue et al., (2003); Thompson et al., (2003); and Sirvent et al., (2005).

Chromosomal aberration test has a great importance because it detects, identifies, and clarifies agents that may cause chromosomal abnormalities in the mammalian cells (Galloway et al., 1987). It may be common cause of many human genetic disorders and involved in induction of cancer in humans and also in the experimental animals (FDA, 2003).

Moreover, FDA, (2003) classified chromosomal aberrations into two main categories, structural aberrations and numerical aberrations. The structural aberration is the alteration in chromosomal structure that is detected by microscopic examination of the metaphase of cell division, while the numerical aberration is an alteration in the number of chromosomes from the normal diploid number of the examined cells.

It is worthmentioning that statins may have an influence on genomic damage (Pernice $\boldsymbol{e t}$ al., 2006). Some types of statins such as rosuvastatin can be considered cytotoxic in human peripheral lymphocytes (Berber et al., 2014) since it may increase the chromosomal aberration frequencies.

On the other hand, muscle tissue is fairly homogenous in structure and composition, meaning that the proteins of myocellular structures as the myofibrils and the costameres are among the most abundant in the human body. The resting turnover of muscle proteins is very high (Nedergaard $\boldsymbol{e t}$ $\boldsymbol{a l .}$, 2013), and during critical illness, muscle loss can exceed several percent per day (White $\boldsymbol{e t}$ al., 2011).

Glycogen is the storage form of carbohydrates in mammals. In humans the majority of glycogen is stored in skeletal muscles $(\sim 500 \mathrm{~g})$ and the liver $(\sim 100 \mathrm{~g})$. The glycogen stores in skeletal muscles are limited because an efficient feedback-mediated inhibition of glycogen synthase prevents accumulation (Jensen et al., 2011).

But it's worth mentioning that statins also may cause a diminution in muscle glycogen content and increase the oxidative stress in skeletal muscle, and consequently, cause mitochondrial dysfunction due to reduction of its biogenesis (Bouitbir et al., 2011; and 2012b).

Aim of the work: This study was conducted to investigate the effect of simvastatin on chromosomal aberrations (CAs), skeletal muscles' total proteins (TP), and glycogen (GLYC) content in adult male albino rats. 


\section{Materials \& Methods}

\section{Experimental animals}

This study follows the guidelines of the Ethics Committee and followed the guide for the care and use of laboratory animals. A total of 20 adult male albino rats (Rattus norvegicus), with average age of 10 - 20 weeks, and weighted 60-70 gm were brought from Helwan Breeding FarmCairo, Egypt in September 2015 and were provided with standard diet and water ad labtium and kept to acclimatization in the laboratory environmental conditions for one week.

\section{Drug usage and Dose preparation}

Simvastatin (SIMVACOR® drug by SIGMA Pharmaceutical Company, Egypt) was obtained from the market. Each SIMVACOR ${ }^{\circ}$ tablet contained: Simvastatin $80 \mathrm{mg}$ as the active ingredient. Simvastatin was mashed before oral intake and orally administered using a gastric gavage tube at a dose of $80 \mathrm{mg} / \mathrm{kg}$ body weight (b.wt.)/day according to Farouk et al., (2012). Each tablet was dissolved in $2 \mathrm{ml}$ distilled water to be formulated for dosing as suspension. Doses are modified weekly during the period of 46 days of injection according to the new weight gains.

\section{Experimental Design}

Group I (Cont. Gr.): This group is the control group that contained 10 male albino rats that get no doses of Simvastatin and sacrificed and dissected after 46 days.

Group II (simv. Gr.): This group is the treated group that contained 10 male albino rats injected orally with dissolved SIMVACOR ${ }^{\circledR}$ using gastric gavage tube to induce muscle toxicity.

\section{1- Chromosomal Aberration Assay (CAA)}

* Preparation of Metaphase Chromosomes

Metaphase chromosomes were prepared from bone marrow cells according to the technique described by Agarwal et al., (1994).

\section{* Scoring and statistical analysis}

For each animal, 50 well-spread metaphases were examined and scored to determine the percentage of the total chromosomal aberration by a binocular compound microscope at 1000x magnification according to Tice et al., (1987).

\section{2- Histochemical Examinations}

After scarification, the right gastrocnemius muscle was dissected and fixed in $10 \%$ formalin for routine histochemical studies according to Puchtler \& Meloan, (1985).

2.1. BromoPhenol blue stain (BPB): for detection of total proteins using Image Analyzer software and Olympus BX40 Microscopy.

2.2. Periodic acid-Schiff (PAS): for detection of glycogen as polysaccharides by using Image Analyzer unit and Olympus BX40 Microscopy.

\section{3- Statistical analysis}

The obtained results were subjected to One-Way ANOVA using IBM SPSS Statistics Program Version 19 with a significance value of $(\mathrm{P}<0.05)$. Microsoft Excel Office 2007 was also used. 
Results

1- Chromosomal Analysis for Detection of Chromosomal Aberration

Table (1): The percentage of structural and numerical chromosome aberrations in bone marrow cells of rats after exposure to Simvastatin.

\begin{tabular}{|c|c|c|c|c|c|c|c|c|c|c|c|c|c|c|c|c|}
\hline Group & 总 & \multicolumn{15}{|c|}{ Structural and Numerical Chromosomal Aberrations / 300 cells } \\
\hline $\begin{array}{l}\text { Group } \\
\text { I } \\
\text { (Cont. } \\
\text { Gr.) }\end{array}$ & 300 & 19 & 13 & 20 & 3 & 3 & 6 & 6 & 21 & 8 & 10 & 3 & 2 & 114 & \multirow[t]{2}{*}{$\begin{array}{c}9.5 \pm \\
2\end{array}$} & \multirow[t]{2}{*}{----- } \\
\hline $\begin{array}{c}\text { C. } \\
\text { A. } \%\end{array}$ & & 6.3 & 4.3 & 6.6 & 1 & 1 & 2 & 2 & 7 & 2.6 & 3.3 & 1 & 0.6 & 38 & & \\
\hline $\begin{array}{l}\text { Group } \\
\text { II } \\
\text { (Simv. } \\
\text { Gr.) } \\
\end{array}$ & 300 & 23 & 19 & 14 & 8 & 5 & 1 & 11 & 39 & 15 & 7 & 2 & 3 & 147 & $\begin{array}{c}12.2 \pm \\
3.1\end{array}$ & $P=N . S$. \\
\hline \multicolumn{17}{|c|}{$\begin{array}{l}\text { Cont. Gr. = Control group, Simv. = Simvastatin } \\
\text { By } t \text {-test, } \mathrm{P}<0.05 \\
\mathrm{P}=\text { vs control group }\end{array}$} \\
\hline
\end{tabular}




\subsection{Chromosomal Aberrations of Group I (Cont. Gr.)}

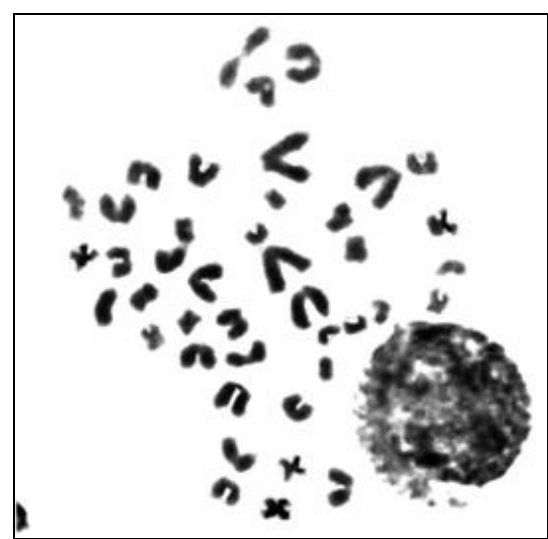

1)

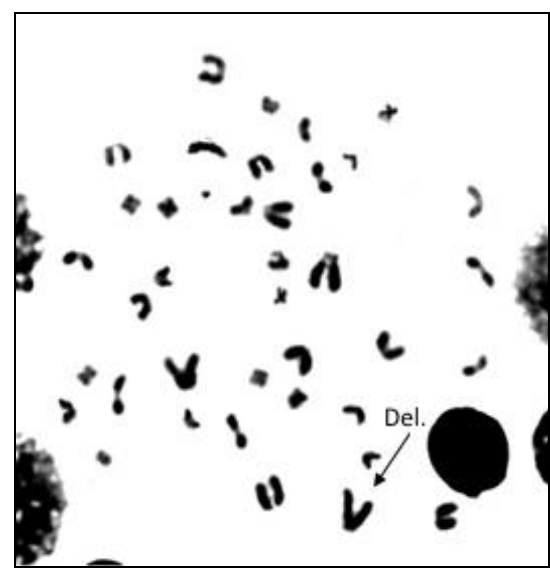

4)

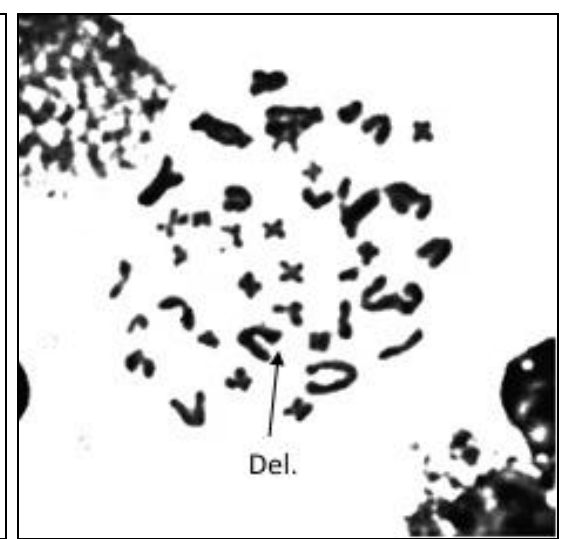

2)

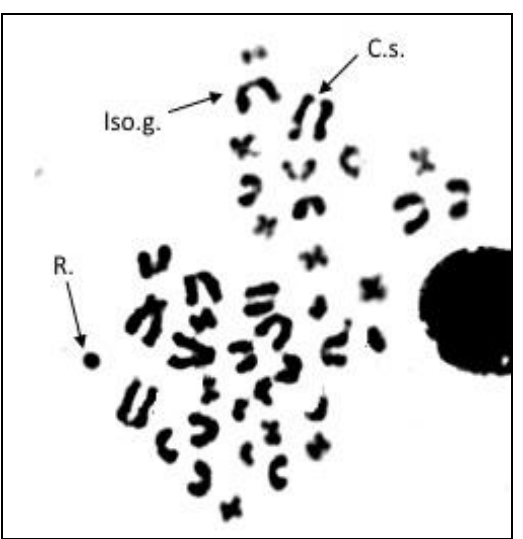

3)

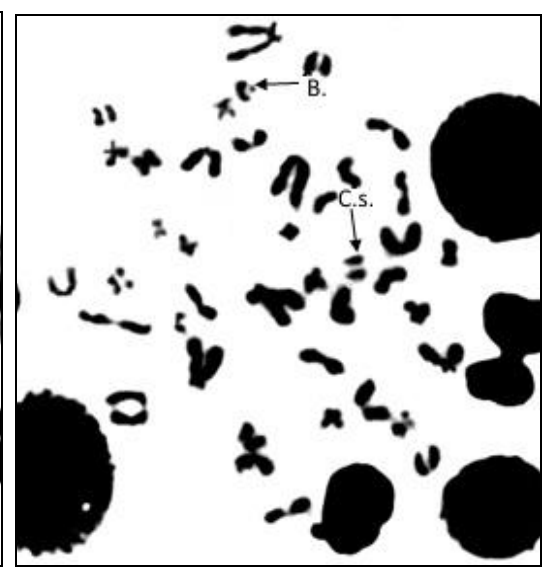

5)

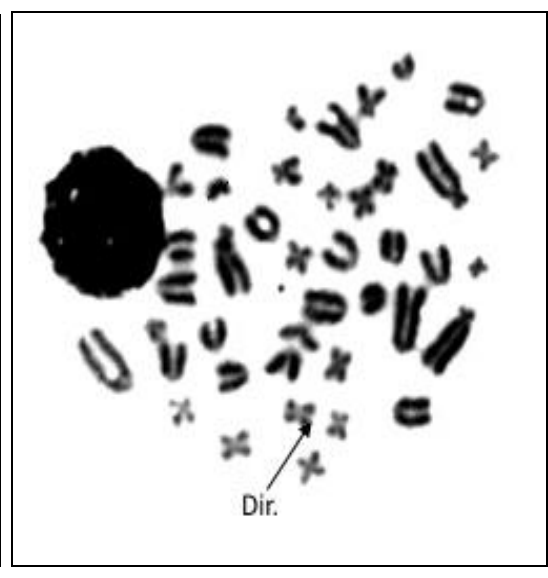

6)

Fig. (1): Metaphase spreads from BM cells of rats of Group I (Cont. Gr.) showing some structural aberrations (SAs) as: 1) Normal metaphase with diploid number (42 chromosome), 2) Del., 3) C.S., Iso.G., \& R., 4) Del., 5) B. \& C.S., \& 6) Dir., Magnification X 1000.

Data presented in table (1) showed that animals of Group I (Cont. Gr.) showed different signs of chromosomal aberrations that were recorded in few metaphases. The most prevalent chromosomal aberrations were the deletions, Chromatid gaps, dicentric fusions, and the centric separations with $\%$ of $(6.3 \%, 4.3 \%, 6.6 \%$, and $7 \%$, respectively). Also, data revealed that most of the examined cells showed 42 chromosomes which observed in $95 \%$ of the examined cells. The remaining percent of metaphases are those have less or more than the normal diploid number. Therefore, $3.3 \%$ of the counted cells had hypoploid number of chromosomes, while $1 \%$ had the hyperploid number, and $0.6 \%$ were polyploid. 
1.2. Chromosomal Aberrations of Group II (Simv. Gr.)

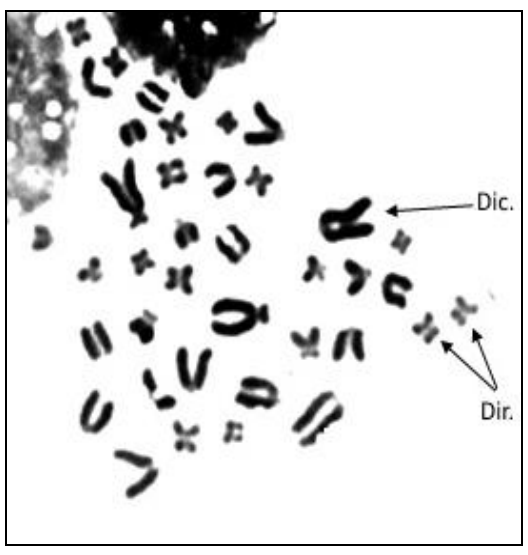

1)

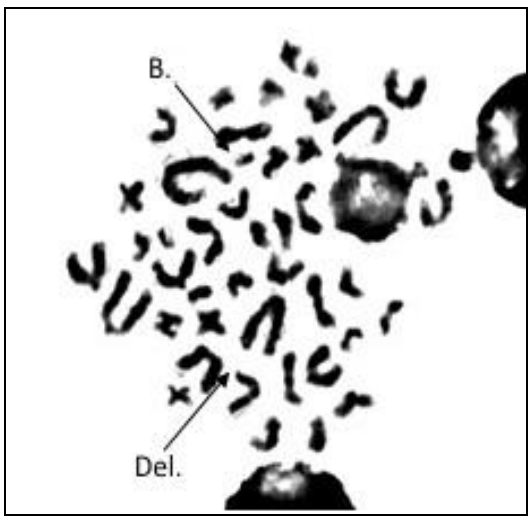

4)

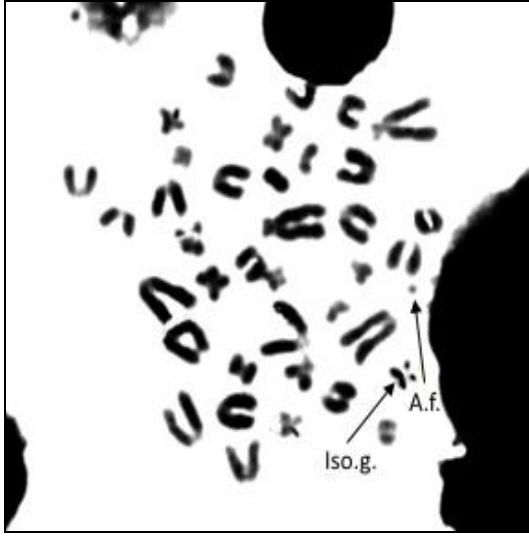

2)

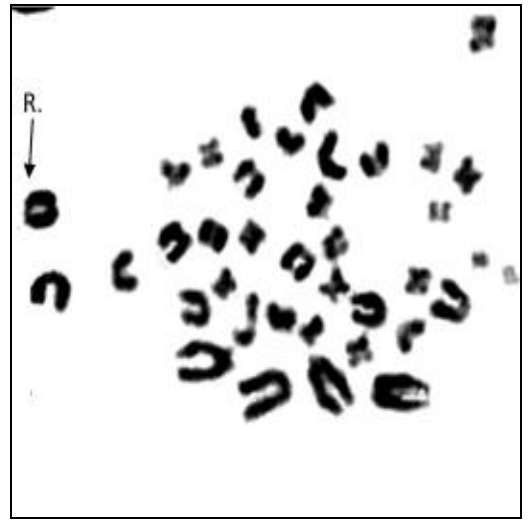

5)

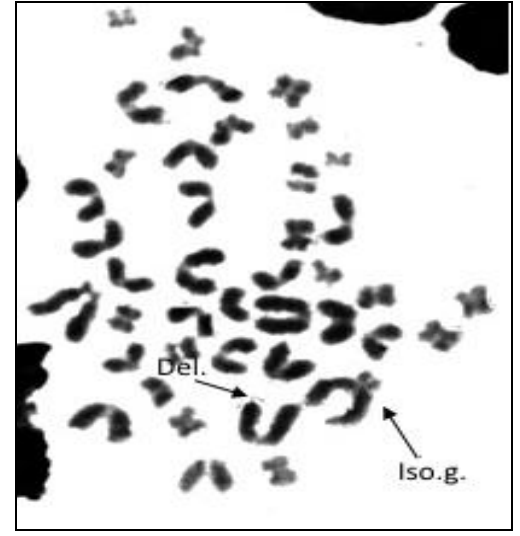

3)

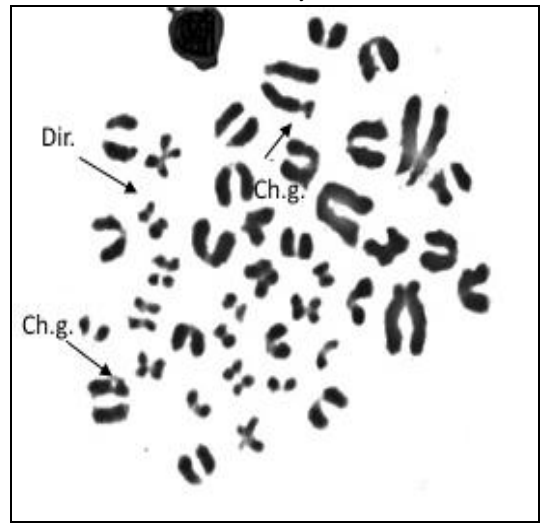

6)

Fig. (2): Metaphase spreads from BM cells of rats of Group II (Simv Gr.) showing some structural aberrations (SAs) as: 1) Dir. \& Dic., 2) Iso.G. \& A.F., 3) Iso.G. \& Del., 4) Del. \& B. 5) R., \& 6) Ch.G. \& Dir., Magnification X 1000.

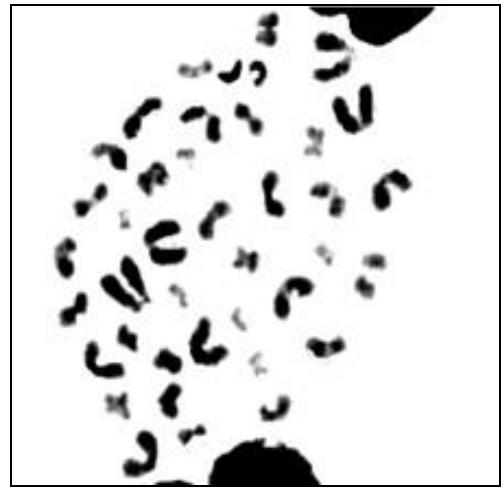

1)

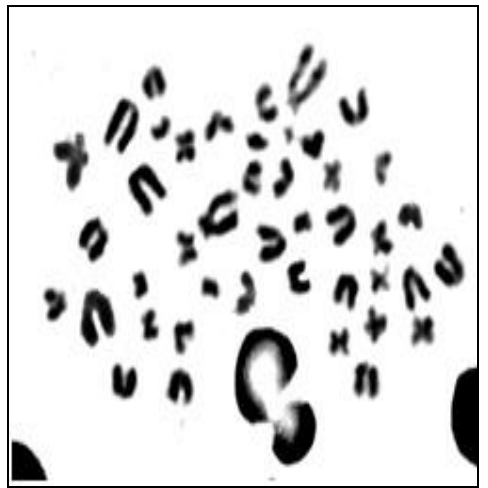

2)

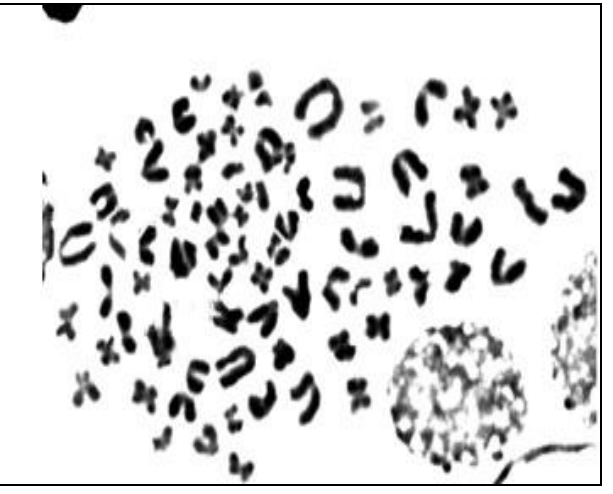

3)

Fig. (3): Metaphase spreads from BM cells of rats of Group II (Simv Gr.) showing numerical aberration (NAs) as: 1) Hypoploid with 41 chromosomes, 2) Hyperploid with 43 chromosomes, 3) Polyploid with multiplication of the diploid number. Magnification X 1000. 
Data presented in table (1) showed different signs of chromosomal aberrations which were recorded in the treated group. The most prevalent aberrations were the deletions, chromatid gaps, dicentric fusions, and the centric separations with $\%$ of $(7.6 \%, 6.3 \%, 4.6 \%$, and $13 \%$, respectively). Also, the same data showed that most of the examined cells showed 42 chromosomes which observed in $96 \%$ of the examined cells. The remaining percent of metaphases are those which have less or more than the normal diploid number. Therefore, $2.3 \%$ of the counted cells had hypoploid number of chromosomes, while $0.6 \%$ had the hyperploid number, and $1 \%$ were polyploid.

\section{2- Histochemical Examination of skeletal Muscles for Determination of Total Proteins and Glycogen Contents}

2.1. BromoPhenol blue stain (BPB): for detection of total proteins using Image Analyzer software and Olympus BX40 Microscopy.

Table (2): Effect of Simvastatin on the total protein of the control and experimental groups of male rats.

\begin{tabular}{|l|c|c|}
\hline \multicolumn{1}{|c|}{$\begin{array}{c}\text { Groups } \\
\text { n = 10 } \text { rats }\end{array}$} & Mean \pm S.E.M. & \% Change from control \\
\cline { 2 - 3 } Group I (Cont. Gr.) & $117.76 \pm 3.3$ & ---- \\
\hline Group II (Simv. Gr.) & $112.22^{\mathrm{NS}} \pm 2.4$ & $-4.7 \%$ \\
\hline $\begin{array}{l}\text { n= number of rats in each group, Cont. Gr. = Control group, Simv. = Simvastatin } \\
\text { By ANOVA, P }<0.05 . \\
\text { NS = Not significant }=\mathrm{P}>0.05\end{array}$ \\
\hline
\end{tabular}

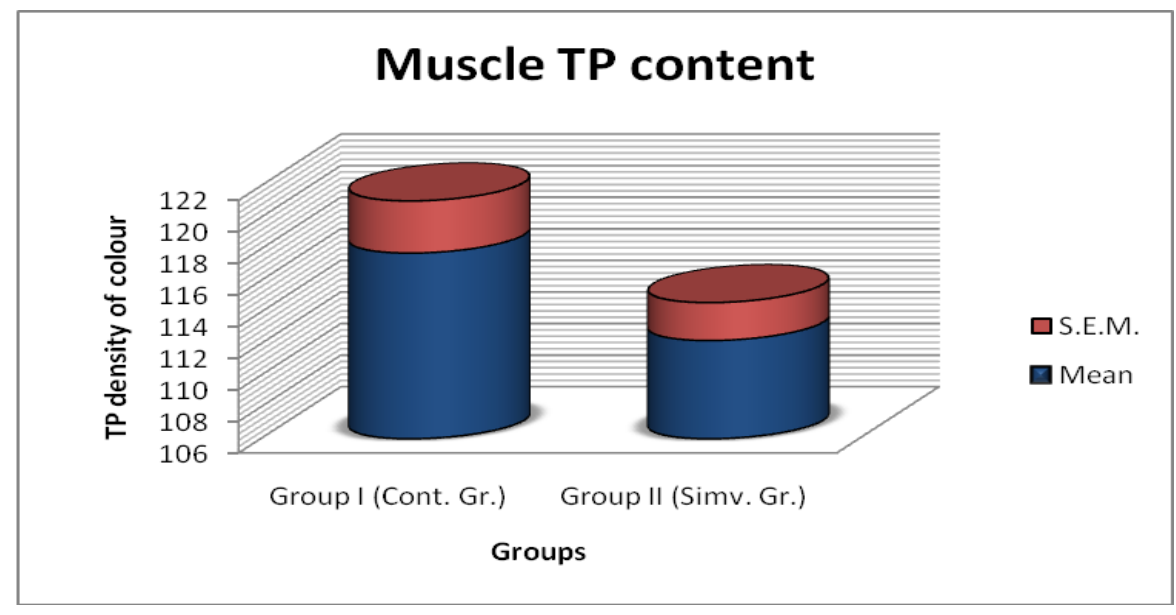

Fig. (4): Mean \pm S.E.M. of total protein content in gastrocnemius muscles in different groups.

A non-significant decrease was recorded in the total protein (TP) content of the treated samples comparing to the control group (Table $2 \&$ fig. 4). Such decrease reached to $(-4.7 \%)$. 
2.2. Periodic acid-Schiff (PAS): for detection of glycogen as polysaccharides by using Image Analyzer unit and Olympus BX40 Microscopy.

Table (3): Effect of Simvastatin on the glycogen content of the control and experimental groups of male rats.

\begin{tabular}{|c|c|c|}
\hline \multirow{2}{*}{$\begin{array}{c}\text { Groups } \\
\mathbf{n}=\mathbf{1 0} \text { rats }\end{array}$} & \multicolumn{2}{|c|}{ Glycogen's density of colour } \\
\hline & Mean \pm S.E.M. & \% Change from control \\
\hline Group I (Cont. Gr.) & $125.87 \pm 0.2$ & ----- \\
\hline Group II (Simv. Gr.) & $101.92^{\mathrm{a}} \pm 0.6$ & $-19 \%$ \\
\hline \multicolumn{3}{|c|}{$\begin{array}{l}\mathrm{n}=\text { number of rats in each group, Cont. Gr. = Control group, Simv. = Simvastatin } \\
\text { By ANOVA, } \mathrm{P}<0.05 \\
\mathrm{a}=\mathrm{P}<0.05 \text { vs Cont. Gr. }\end{array}$} \\
\hline
\end{tabular}

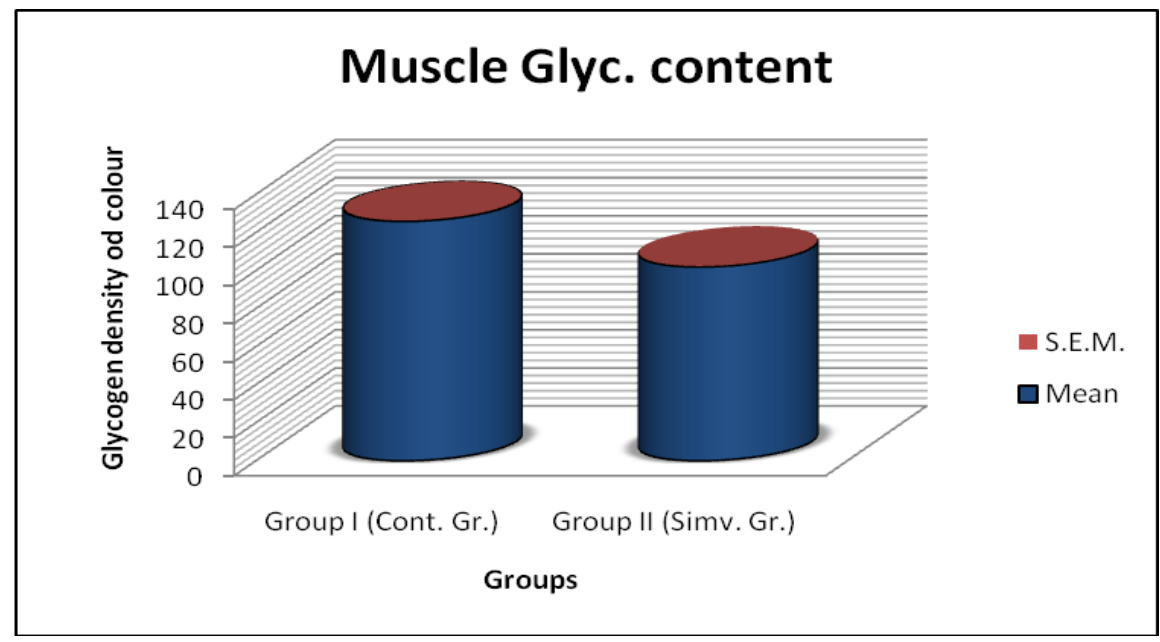

Fig. (5): Mean \pm S.E.M. of glycogen content in gastrocnemius muscles in different groups.

On the other hand, significant decrease was observed in the glycogen content of the treated rats comparing to that of the control group. The value of such decrease reached $(-19 \%)$ (Table 3 and fig. 5).

\section{Discussion}

Statins exhibit pleiotropic beneficial properties beyond cholesterol-lowering effects since they considered as anti-inflammatory and anti-oxidative drugs and are clinically well established for the prevention of cardiovascular diseases (Henninger \& Fritz, 2017). Unfortunately, although statins are generally regarded safe drugs, the most common statin related adverse reaction is skeletal muscle toxicity that ranges from mild to severe (Norata et al., 2014).

There are many test methods used to detect the potential genotoxicity of different chemicals. Chromosomal aberration test can be considered as very sensitive methods for that (Yilmaz et al., 
2008). Chromosomal analysis for detection of chromosomal aberrations can be considered as one of very important tests that check for the genotoxic potentiality of any substance or chemical compound including statin drugs (Berber et al., 2014).

In the present study, 9 types of SCAs have been recorded in the investigated groups but in different percentages. Those SCAs were: Deletions (Del.), Chromatid Gaps (Ch. G.), Dicentric fusions (Dic.), Isochromatid gaps (Iso. G.), Breaks (B.), Rings (R.), Accentric fragments (A. F.), Centric Separations (C. S.), and Diradials (Dir.), with an increase in the means of total CAs of Group II (Simv. Gr.) comparing to control samples as (12.2 \pm 3.1 versus $9.5 \pm 2$, respectively).

Actually, literatures related to pharmacological effects and therapeutic uses of simvastatin are available, whereas, data concerning to the mutagenic assays involved in the current study are lacking in animal or even in human. Similarly, Berber et al., (2014) mentioned the same observation about finding enough scientific researches that deal with and discuss the genotoxicity of rosuvastatin.

The present result was at variance with Berber $\boldsymbol{e t}$ al., (2014) who detected a significant increase in the chromosomal aberration frequencies in patients who received rosuvastatin as treatment for hypercholesterolemia when compared to the negative controls. Berber $\boldsymbol{e t}$ al. suggested that rosuvastatin can be considered as cytotoxic agent.

But on the other hand, the present findings disagree with FDA, (2012) reports when mentioned that simvastatin doesn't cause any damage to genetic material either in vitro chromosome aberration study in Chinese hamster ovary $(\mathrm{CHO})$ cells, or in vivo chromosomal aberration assay in mouse bone marrow.

The present results were at variance with the data previously obtained by Gong, (2003) who found that rosuvastatin did not show any mutagenic potential through chromosomal aberration assay in mice.

Therefore, the present increase in CAs in the treated group may be due to the effect of simvastatin on the genetic material. And hence, simvastatin can be considered as cytotoxic agent.

On the other hand, since muscle protein metabolism is a dynamic process characterized by the balance between the synthesis and breakdown of muscle proteins, Fry \& Rasmussen, (2011) reported that a disturbance in this equilibrium can lead to the loss of muscle mass, and a disturbance of muscle protein turnover.

In the present study, there was an observed non significant decrease in the mean of total proteins' content in the gastrocnemius muscles of the experimental group when compared to that of the -ve control group with \% of change of (-4.7\%).

The present finding was in consistence with Southern et al., (2017) who found an alteration in protein synthesis in male C57BL/6J wildtype mice receiving simvastatins and got muscle atrophy. This could be attributed to a shift in the balance between muscle protein synthesis and muscle protein degradation toward protein degradation that results in muscle atrophy.

In addition, Ozek et al., (2014) demonstrated a decrease in protein content in male Wister rats' muscles after administration of simvastatin, and stated that this might be due to an increase in protein degradation after usage of proteins as an alternative source of energy. Moreover, in a 
previous study, Ozek et al., (2010) found also a reduction in the protein content in simvastatintreated fast-extensor digitorum longus (EDL) muscle.

Camerino et al., (2011) suggested that this reduction may be due to a reduction in protein synthesis after exposure to statin which causes alterations in the proteomic profile of EDL muscle when stated that simvastatin injection leads to down regulation in the proteins expression such as actin, myosin, and troponin.

In the other way, the intramyofibrillar glycogen is a very important store for glycogen so the reduction of the glycogen content in skeletal muscles is highly correlated with skeletal muscle fatigue (Nielsen et al., 2010).

The present results showed a significant decrease in glycogen's content in the gastrocnemius muscles of the treated group with a percentage of change from the control was found to be ($19.02 \%)$.

This was in agreement with Bouitbir et al., (2011) who found that rats which are treated orally with atorvastatin, got a reduction in muscular glycogen content. Bouitbir et al. hypothesized this due to a reduction in glycogen synthesis and/or a reduction in muscle glucose uptake. In addition, Ozek et al., (2010) demonstrated that simvastatin induced a significant decrease in glycogen content in male Wistar rats' extensor digitorum longus muscle.

Ozek et al., (2014) also reported a reduction in glycogen content in male Wister rats' muscles after 30 days of simvastatin with dosage of $50 \mathrm{mg} / \mathrm{kg}$ b.wt. Similarly, Bouitbir et al., (2011); and (2012b) reported that atorvastatin may increase the production and concentration of reactive oxygen species (ROS) and reduce the maximum mitochondrial respiration, and muscle glycogen content in skeletal muscle of mice, indicating that the statins may induce oxidative stress in skeletal muscle and, consequently, cause mitochondrial dysfunction due to reduction of its biogenesis.

On contrary, the present diminution in glycogen's muscle content disagrees with Lorenzoni $\boldsymbol{e t}$ al., (2007) who reported a case of 35-years old man who acquired rosuvastatin-induced rhabdomyolysis and investigations cleared that in muscle biopsy, subsarcolemmal and central acummulation of glycogen were noticed.

\section{Summary and Conclusion}

Finally, based on the present results, simvastatin treatment induced non-significant increase in structural and numerical aberrations indicated its slight clastogenic and its spindle poisoning actions. In the other hand, the non-significant decrease in the level of total proteins content and the significant reduction in the level of glycogen content pointed to disturbances in the biochemical constituents of the skeletal muscles of rats. Therefore, simvastatin should be cautiously used under medical supervision.

\section{References}

Agarwal, D. K., Chauhan, L. K. S., Gupta, S. K., \& Sundararaman, V. (1994) Cytogenetics effects of deltamthrin on rat bone marrow. Mut Res, 311(1), 133-138. 
Ahmad, H. \& Cheng-Lai, A. (2010) Pitavastatin: a new HMG-CoA reductase inhibitor for the treatment of hypercholesterolemia. Cardiol Rev, 18(5), 264-267.

Bouitbir, J., Charles, A. L., Echaniz-Laguna, A., Kindo, M., Daussin, F., et al. (2012a) Opposite effects of statins on mitochondria of cardiac and skeletal muscles: a 'mitohormesis' mechanism involving reactive oxygen species and PGC-1. Eur Heart J, 33(11), 13971407.

Bouitbir, J., Charles, A. L., Rasseneur, L., Dufour, S., Piquard, F., et al. (2011) Atorvastatin treatment reduces exercise capacities in rats: involvement of mitochondrial impairments and oxidative stress. J Appl Physiol, 111(5), 1477-1483.

Bouitbir, J., Daussin, F., Charles, A. L., Rasseneur, L., Dufour, S., et al. (2012b) Mitochondria of trained skeletal muscle are protected from deleterious effects of statins. Muscle Nerve, 46(3), 367-373.

Berber, A. A., Celik, M., \& Aksoy, H. (2014) Genotoxicity evaluation of HMG CoA reductase inhibitor rosuvastatin. Drug Chem Toxicol, 37(3), 316-321.

Camerino, G. M., Pellegrino, M. A., Brocca, L., Digennaro, C., Camerino, D. C., et al. (2011) Statin or fibrate chronic treatment modifies the proteomic profile of rat skeletal muscle. Biochem Pharmacol, 81(8), 1054-1064.

Farouk, A. A., El-Stoohy, F., Ali, S. E., Abd El-Atty, H., Rashed, L., et al. (2012) Influence of Stem Cell Therapy on Statin-induced Myopathy of Skeletal Muscle in Female Rats. TJN, 18(4), 135-144.

Fischer, S., Schatz, U., \& Julius, U. (2015) Practical recommendations for the management of hyperlipidemia. Atheroscler Suppl,18, 194-198.

Food \& Drug Administration (FDA) (2003) Toxicological Principles for the Safety Assessment of Food Ingredients Redbook 2000. Chapter IV.C.1.b. In vitro Mammalian Chromosomal Aberration Test.

Food \& Drug Administration (FDA) (2012) Mevacor (lovastatin) tablets. http://www.fda.gov/safety/medwatch/safetyinformation/ucm295611.htm

Fry, C. S. \& Rasmussen, B. B. (2011) Skeletal muscle protein balance and metabolism in the elderly. Curr Aging Sci, 4(3), 260-268.

Galloway, S. M., Armstrong, M. J., Reuben, C., Colman, S., Brown, B., et al. (1987) Chromosome aberration and sister chromatid exchanges in Chinese hamster ovary cells: Evaluation of 108 chemicals. Environ Mol Mutagen, 10(Suppl10), 1-175.

Gong, J. (2003) Advisory Committee Brief Document, Pharmacology. NDA No. 21-366

Henninger, C. \& Fritz, G. (2017) Statins in anthracycline-induced cardiotoxicity: Rac and Rho, and the heartbreakers. Cell Death Dis, 8(1), e2564.

Inoue, R., Tanabe, M., Kono, K., Maruyama, K., Ikemoto, T., \& Endo, M. (2003) $\mathrm{Ca}^{2+}$-releasing effect of cerivastatin on the sarcoplasmic reticulum of mouse and rat skeletal muscle fibers. J Pharmacol Sci, 93, 279-288.

Iughetti, L., Bruzzi, P., \& Predieri, B. (2010) Evaluation and management of hyperlipidemia in children and adolescents. Curr Opin Pediatr, 22(4), 485-93. 
Jasinska, M., Owczarek, J., \& Orszulak-Michalak, D. (2007) Statins: a new insight into their mechanisms of action and consequent pleiotropic effects. Pharmacol Rep, 59(5), 483-99.

Jensen, J., Rustad, P. I., Kolnes, A. J., \& Lai, Y. (2011) The Role of Skeletal Muscle Glycogen Breakdown for Regulation of Insulin Sensitivity by Exercise. Front Physiol, 2, 112.

Lorenzoni, P. J., Silvado, C. E., Scola, R. H., Luvizotto, M., \& Werneck, L. C. (2007) McArdle disease with rhabdomyolysis induced by rosuvastatin: case report. Arq Neuropsiquiatr, $65(3 b), 834-837$.

Maghsoodi, N. \& Wierzbicki, A. S. (2016) Statins: general safety profile and association with myopathy. Clinic Pharm, 8(5).

Nedergaard, A., Karsdal, M. A., Sun, S., \& Henriksen, K. (2013) Serological muscle loss biomarkers: an overview of current concepts and future possibilities. $J$ Cachexia Sarcopenia Muscle, 4(1), 1-17.

Nielsen, J., Suetta, C., Hvid, L. G., Schroder, H. D., Aagaard, P., et al. (2010) Subcellular localization-dependent decrements in skeletal muscle glycogen and mitochondria content following short-term disuse in young and old men. Am J Physiol Endocrinol Metab. 299, E1053-1060.

Norata, G. D., Tibolla, G., \& Catapano, A. L. (2014) Statins and skeletal muscles toxicity: from clinical trials to everyday practice. Pharmacol Res, 88, 107-113.

Ozek, N. S., Bal, I. B., Sara, Y., Onur, R., \& Severcan, F. (2014) Structural and functional characterization of simvastatin-induced myotoxicity in different skeletal muscles. Biochim Biophys Acta, 1840(1), 406-415.

Ozek, N.S., Sara, Y., Onur, R., \& Severcan, F. (2010) Low dose simvastatin induces compositional, structural and dynamic changes in rat skeletal extensor digitorum longus muscle tissue. Biosci Rep, 30(1), 41-50.

Pernice, F., Floccari, F., Caccamo, C., Belghity, N., Mantuano, S., et al. (2006) Chromosomal damage and atherosclerosis. A protective effect from simvastatin. Eur J Pharmacol, 532(3), 223-229.

Puchtler, H. \& Meloan, S. N. (1985) On the chemistry of formaldehyde fixation and its effects on immunohistochemical reactions. Histochem, 82(3), 201-204.

Sirvent, P., Mercier, J., Vassort, G., \& Lacampagne, A. (2005) Simvastatin triggers mitochondria-induced $\mathrm{Ca}^{2+}$ signalling alteration in skeletal muscle. Biochem Biophys Res Commun, 329(3), 1067-1075.

Southern, W. M, Nichenko, A. S., Shill, D. D., Spencer, C. C., Jenkins, N. T., et al. (2017) Skeletal muscle metabolic adaptations to endurance exercise training are attainable in mice with simvastatin treatment. PLoS ONE, 12(2), e0172551.

Thompson, P. D., Clarkson, P., Karas, R. H. (2003) Statin-associated myopathy. JAMA, 289, 1681-1690.

Tice, R. R., Luce, C. A., Chelby, M. D. (1987) Methyl isocyanate: an elevation of in vivo cytogenetic activity. Inviron Mutagen, 9, 37-50. 
White, J. P., Baynes, J. W., Welle, S. L., Kostek, M. C., Matesic, L. E., et al. (2011) The regulation of skeletal muscle protein turnover during the progression of cancer cachexia in the Apc(Min/+) mouse. PLoS One, 6(9), e24650.

Wilke, R. A., Mareedu, R. K., \& Moore, J. H. (2008) The Pathway Less Traveled: Moving from Candidate Genes to Candidate Pathways in the Analysis of Genome-Wide Data from Large Scale Pharmacogenetic Association Studies. Curr Pharmacogenomics Person Med, 6(3), 150-159.

Yilmaz, S., Aksoy, H., Unal, F., Celik, M., \& Yüzbaşloğlu, D. (2008). Genotoxic action of fungicide conan 5FL (hexaconazole) on mammalian cells in vivo and in vitro. Genetika, 44(3), 323-328. 


\section{تأثير السمفاستاتين على ذكور الجرذان البالغة. دراسات وراثية خلوية وكيميائية نسيجية

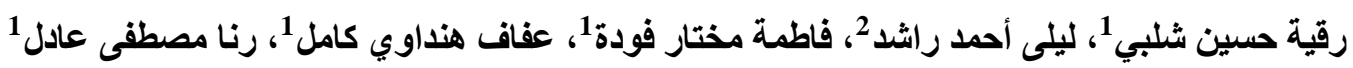 \\ !. قسم علم الحيو ان، كلية البنات للآداب و العلوم و التربية، جامعة عين شمس، القاهرة، مصر. \\ r ب. قسم الكيمياء الحيوية، كلية الطب، جامعة القاهرة، القاهرة، مصر. \\ المستخلص العربي}

المقدمة: ينتمي السمفاستاتين لأدوية الستاتين و التي تستخدم على الصعيد العالمي لخفض مستوى الكوليستيرول في الدم في

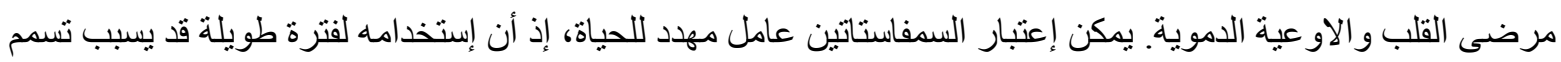
للعضلات. المواد والطرق المستخدمة: أجريت التجربة الحالية على عدد 20 من الجرذان البالغة، حيث قسمت الى مجمو عتين: المجمو عة I و هي المجمو عة الضابطة والتي لم تتلقى أى معالجة، و المجمو عة II وهي المجمو عة المعالجة و التي تم تجريعها

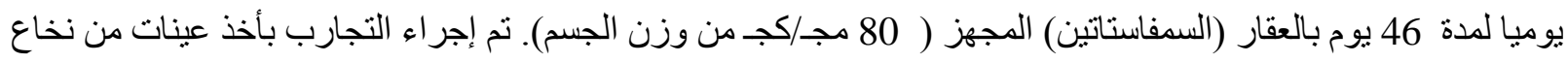

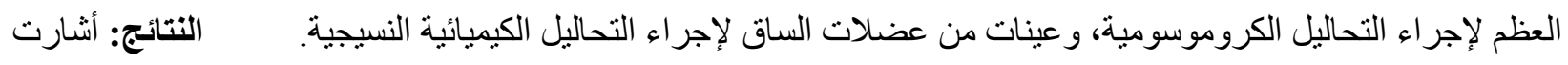

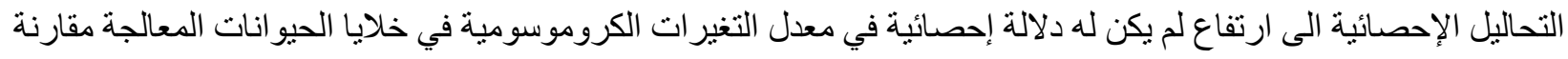
بالعينات الضابطة. من جهة اخرى، لوحظ إنخفاض ليس له دلالة إحصائية في منوسط محتوى البروتينات الكلية لعضلة الساق للمجموعة لمند مقارنتها بالعينات الضابطة. في المقابل، لوحظ إنخفاض ذو دلالة إحصائية في متوسط محتوى الجلايكو جين

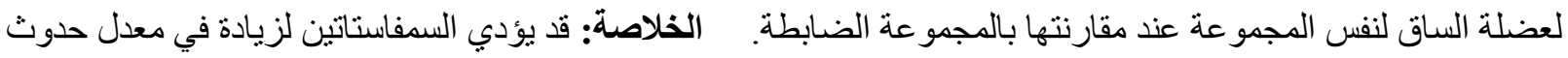

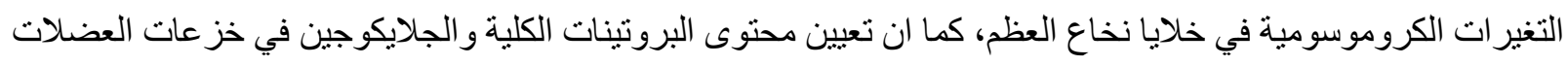

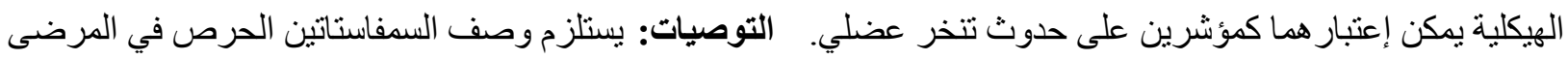
الذين يعانون من فرط كوليستيرول الدم، يجب أخذ الإحتياطات في عين الإعتبار حيث أنه يمكن أن يؤثر على صحة العضلات العنات الهيكلية ويؤدي إلى تسمم العضلات على المدى القصير او الطويل من الإستخدام. 